\title{
Corak Pemikiran Hukum Teologi Asy'ariyyah; Studi Pemikiran Hukum Abu Hâmid Al-Ghazâli (450 H - 505 H) Dalam Al-Mustashfâ Min 'Ilm Al-Ushûl
}

\author{
Azi Ahmad Tadjudin \\ STAI DR. KHEZ. Muttaqien Purwakarta, Indonesia \\ azi.tadjudin@gmail.com
}

\begin{tabular}{l}
\hline \\
\hline Kata kunci: \\
Ijtihâd \\
Tashwîb \\
Qathi'i \\
Zhanny
\end{tabular}

\begin{abstract}
ABSTRAK
Polemik terkait masalah al- $\underline{H u s n}$ wa al-Qubh al-'aqliyayn telah mejadi perdebatan panjang antara kubu Mu'tazilah dengan Asy'ariyyah. Polemik ini hampir menghiasi lembaran kitab Ushul Fiqih yang ditulis para ulama pasca Imam al-Bâqillâni. Argumentasi mereka dalam membahas alQubh tidak jauh berbeda dengan pembahasan yang telah dibahas oleh para pendahulunya. Kesamaan pola dan jawaban mengenai masalah ini (al-husn wa al-Qubh) mencerminkan identitas (eksistensi) sekaligus meneguhkan pola dan kecenderungan paradigma Madzhab Kalam dalam mewarnai corak

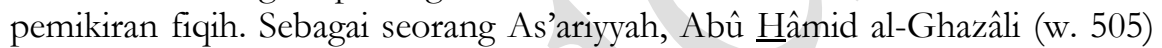
Menyatakan bahwa Ushul Fiqih adalah qath'i, karena ia berdiri di atas pijakan kalam yang juga bersifat qath'i hingga berimplikasi pada cara pandang dan status produk ijtihad. Fiqih sebagai produk ijtihad pada wilayah zhanniyyât dihukumi tidak berdosa, namun hukum yang sama tidak berlaku dalam ranah qathiyyât, karena kesalahan ijtihad dalam ranah ini berakibat dosa bahkan menyandang status kâfir.Teori yang digunakan dalam penelitian ini adalah Teori al-Tashwîb Fî al-Ijtihâd teori ini menyatakan bahwa setiap hasil ijtihad itu (pasti) benar (Kullu Mujtahid[in] Mushîb[un] Fi Ijtihadihi). Teori ini diikuti oleh Pengikut Madzhab Asy'ari (Asy'ariyyah), Mu'tazilah, termasuk alGhazâli dan al-Bâqillâni. Penelitian ini bersifat doktrinal yang akan menyingkap doktrin hukum al-Ghazali dalam kitab al-Mustashfâ Min 'Ilm alUshûl melalui pendekatan analisis tekstual terhadap: (1) masalah-masalah fiqih, (2) klasifikasi objek pebahasan, (3) landasan pemikiran, (4) pendapat yang disepakati, (5) pendapat yang diperselisihkan, (6) diksi keyakinan pendapat, (7) diksi menyikapi perbedaan pendapat, (8) wilayah/ranah pemikiran. Hasil penelitian ini menyimpulkan bahwa konsep Nazhariyyat Qath'iyyat dan Zhanniyyat yang dikemukakan al-Ghazâli merupakan upaya proteksi pemikiran Kalam madzhab Asy'ari dari pengaruh pengaruh pemikiran kalam Mu'tazilah, yang berimbas pada masalah fiqih dan bahasa, sehingga paradigma hukum Madzhab al-Mushawwibah bersifat tegas, menutup ragam kebenaran (tashwîb) dalam wilayah-wilayah pemikiran yang bersifat Qath'iyyat.
\end{abstract}

Copyright C 2020 (Azi Ahmad Tadjudin). DOI: https://doi.org/10.52593/mtq.01.1.01 Naskah diterima: 2 Januari 2020, direvisi: 13 Maret 2020, disetujui: 30 Juni 2020

\section{A. Pendahuluan}

Mu'tazilah dengan Asy'ariyyah pada prinsipnya sepakat bahwa sumber pengetahuan yang hanya dapat diketahui berdasarkan akal yaitu pengetahuan tentang Allah swt dan sifatNya. Kemudian mereka juga bersepakat bahwa pengetahuan yang bersumber dari naqli harus dikonfirmasi oleh aqli dalam urusan ibadah, jinayah dan muamalah. Selain itu, ulama 
ushul - baik dari Mu'tazilah dan Asy'ariyyah-- bersepakat bahwa al- $\underline{H} a \hat{k} i m$ hanya Allah swt. ${ }^{1}$ Otoritas pembuat hukum dalam Islam hanya milik Allah swt. hal ini berdasarkan ayat alQur'an ini al-bukm illâ lillah. Pengakuan Allah swt. sebagai pembuat dan pemilik hukum merupakan wilayah i'tiqâdi (keyakinan) yang bersifat mutlak. Pengingkaran seorang mu'min atas kedaulatan Allah swt. sebagai pembuat hukum (al- $\underline{H} \hat{a} k i m)$, akan berakibat kufur. ${ }^{2}$ Berdasarkan konsep ini, maka posisi mujtahid hanya sebagai mushbir al-bukm (yang menampakkan hukum), maka produk hukum yang digali berdasarkan ijtihad kebenarannya bersifat relatif. ${ }^{3}$

Al-Bâqillâni mendudukkan wahyu sebagai sumber hukum dalam menghukumi perbuatan manusia (al-busn wa al-Qublh), halal-haram, wajib-nadb, taat-maksiat. Secara prinsip hal ini berbeda dengan Abû Husain al-Bashry yang menempatkan hukum perbuatan manusia pada wilayah akal. Dari perbedaan kedua sudut pandang ini, akan melahirkan konsekwensi yang berbeda secara diametral. Al-Bâqillâni menempatkan akal sebagai objek dalam berijtihad, sebab akal tidak memilik ruang sama sekali dalam menggali hukum (al'aqlu ya yastaqillu bidarkibi), Oleh karena itu, menurut al-Bâqillâni bahwa hukum baik dan buruk bagi perbuatan manusia merupakan otoritas mutlak wahyu dalam menetapkannya. Sedangkan al-Bashry menempatkan akal sebagai subjek dalam berijtihad, sebab hukum perbuatan manusia memberikan ruang pada akal untuk menggali hukum secara mandiri (al'aqlu yastaqillu bi darkibi).

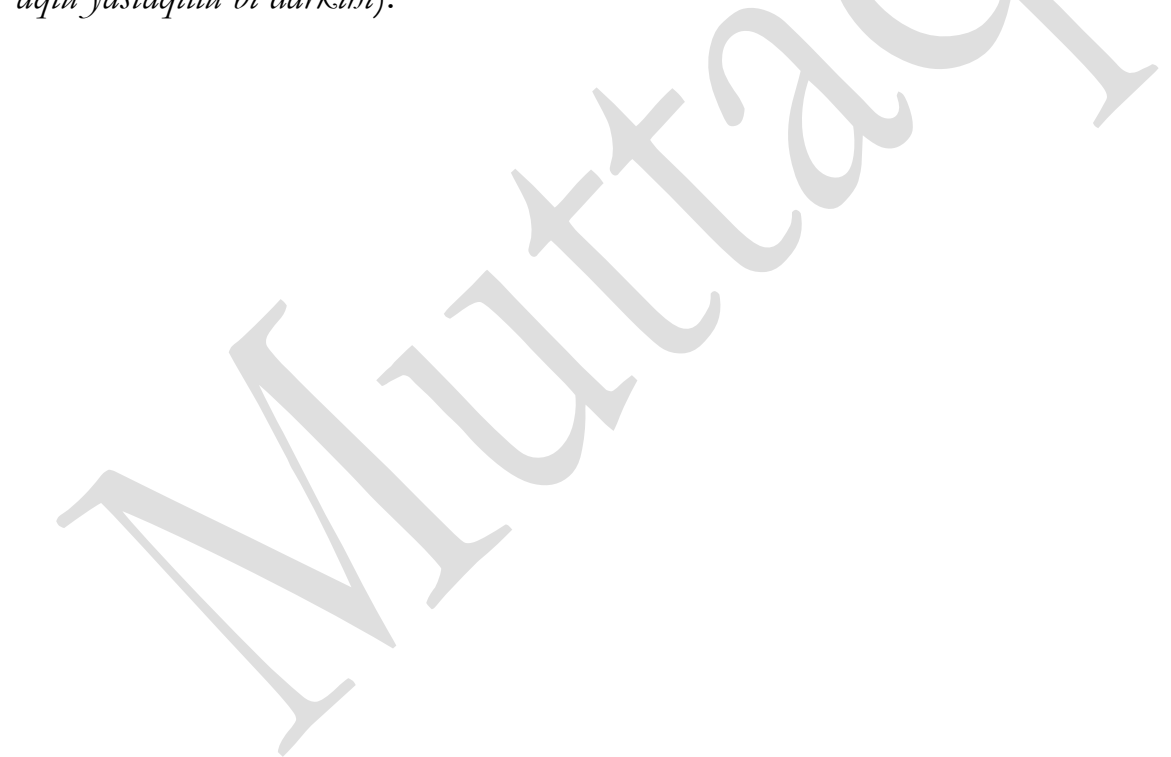

\footnotetext{
${ }^{1}$ Perbedaan sudut pandang Mu’tazilah dengan Asy'ariyyah terletak pada lafazh al-Hâkim ketika difahami sebagai cara untuk mendapatkan hukum (al-Mudrik li al-A hkkâm, al-Muzhzhir). Mu'tazilah berpendapat bahwa akal berpotensi untuk mengetahui hukum syara' secara mandiri. Sedangkan Asy'ari sebaliknya. 'Adil al-Syuwaikh.

2‘Adil al-Syuwaikh., ibid. 24.

${ }^{3}$ contoh ijtihad yang berkaitan dengan dalil yang bersifat zhanny adalah pertentangan antara Abu Hanifah dan Malik ketika menafsirkan lafazh "quru” dalam ayat yang berbicara tentang masa iddah seorang wanita yang dithalaq oleh suaminya. Menurut Abu Hanifah, makna "quru"” adalah al-haidl; sedangkan menurut Malik adalah al-thuhr. Juhaya S Praja "Dinamika Pemikiran Hukum Islam" dalam Jaih Mubarok., op. cit., hlm. viii. Dari kedua pendapat di atas, Ali Al-Shabuni menguatkan pendapat yang disampaikan oleh Abu Hanifah berdasarkan kekuatan argumentasi dalil yang dipakai. Muhammad Ali Al-Shabuni, Rawâ'i al-Bayân Fî Tafsîr Ayât al-Ahkam Min al-Qur'an, (Jakarta: Dar al-Kutub alIslalmiyyah, 2001), 258.
} 


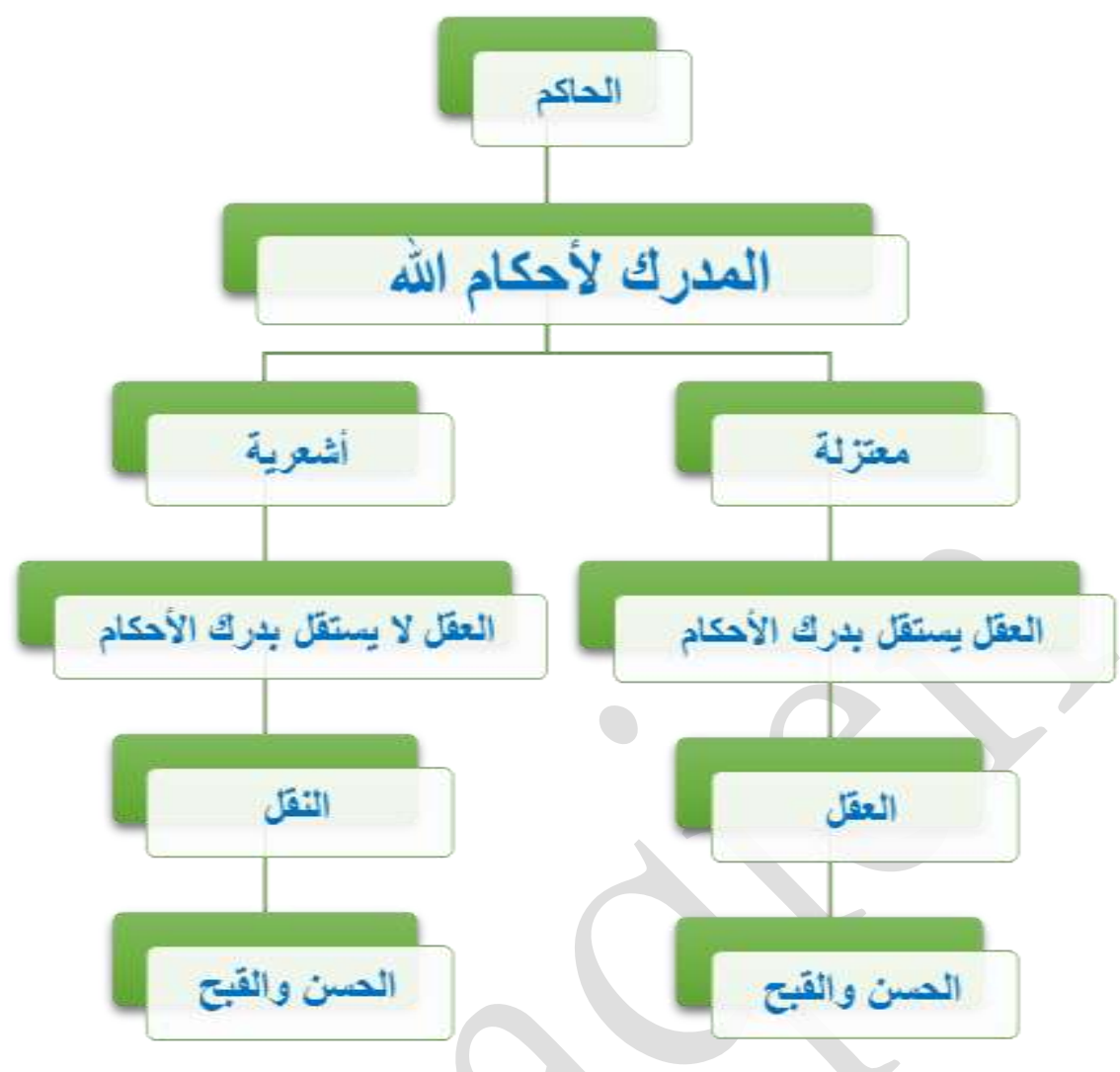

Bagan 1.6 Perbandingan antara Mu'tazilah dengan Asy'ariyyah tentang cara Mengetahui Hukum Allah

Sebagai pengikut Madzhab Asy'ary, Abûtuâmid al-Ghazâli (w. 505) secara sanad keilmuan merupakan metamorfosis dari al-Syâfi'i (w. 204) yang tumbuh dan berkembangan dalam didikan tradisi Sunni pelanjut estafeta alal-Bâqillâny. Al-Ghazali adalah sosok ulama yang sangat diperhitungkan dalam deretan para ulama Madzhab Mutakallimîn. ${ }^{4}$ Hal ini disebabkan karena kontribusi originalitas pemikiran

\footnotetext{
${ }^{4}$ Mutakallimîn adalah orang-orang yang menyibukkan diriya dalam menggeluti ilmu Kalam. Mereka adalah orang-orang yang selalu membantah dengan argumentasi dan dalil-dalil akidah. Dan mereka meyerang pandangan-pandangan keliru yang mempengaruhi keyakinan terhadap musuh-musuh agama yang dianggap menyimpang dan mengikuti hawa nafsu. Alasan istilah ini digunakan karena beberapa sebab, yaitu: (1) mereka memahami ilmu berdasarkan ucapan (kalam) saja seperti menyatakan, "begini dan begitu". (2) masalah kalam menjadi pokok bahasan populer yang menjadi sumber lahirnya perbedaan pendapat. (3) perdebatan kalam berpeluang besar dalam melahirkan 'apriori' tafsir dalam memahi ilmu-ilmu syariat hingga melahirkan fanatik yang menguatkan konflik. Lihat, Ahmad Ibrâhim Hasan al-Hasanât, Tathawwur al-Ushûliy 'inda al-Mutakallimîn (Yordan: Dar an-Nur, 2015), cetakan I, halaman.57. menurut Ibnu Khaldun (w. $785 \mathrm{H}$ ) ilmu kalam adalah ilmu yang berisi tentang argumentasi teologi dan dalil-dalil rasional ('aqliyyah) serta kritik terhadap ahli Bid'ah yang melakukan penyimpangan teologis dari madzhab salaf dan Ahlussunnah. Ibn Khaldun, Muqaddimah (Beirut: Dar al-Ijil, t.th), halaman. 507. Definisi yang sama juga disampaikan oleh Abu Hamid al-Ghazali (w. $505 \mathrm{H}$ ) dalam al-Munqidz Min al-Dhalâl (Lubnan: Dar el-Fikr, 1993), halaman. 59-60. Masih dalam alMunqidz, al-Ghazali mengatakan bahwa ilmu kalam merupakan ilmu yang digunakan untuk membela dan menjaga madzhab Ahl Sunnnah wa al-Jama'ah (Asy'ari) dari serangan ahl al-Bid'ah. Berikut ini pernyataan al-Ghazali dalam al-MunqidzMin al-Dhalâl, halaman. 35.
} 
Ushul Fiqh yang dituangkan dalam al-Mustashfâ menjadi penghubung sekaligus model bagi generasi ulama mutakallimin setelahnya.

Genarasi ulama mutakallimîn pasca al-Ghazâli seperti Fakhruddîn al-Râzî, sangat memperhitungkan intelektualitas al-Ghazali sebagai pembaharu madzhab mutakallimîn. Dalam muqaddimah al-Mabshûl fí ílm al-Ushûl, Taha Jâbir Fayyadh al-'Ulwâni menuliskan:

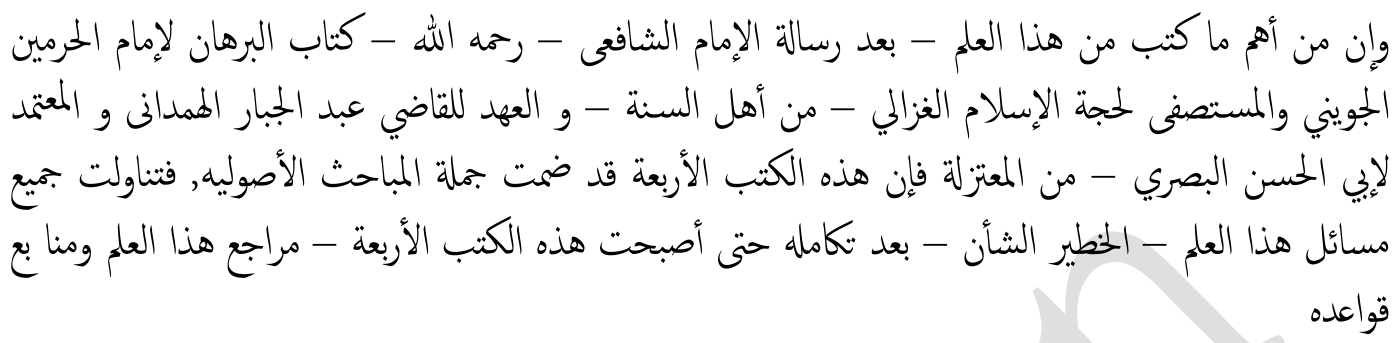

"Diantara kitab -kitab penting (Ushul Fiqib) setelah kitab al-Risalah al-Syafi', yaitu;(1) al-Burban Iman al-Haramayn al-juwaini, (2) al-Mustashfa Hujjah al-Islam al-Ghazali (keduanya dari kalangan abli sunnab), (3) al-'Abd Qadbi abd al-jabbar al-Hamdani, (4) al-Mu'tamad Abu Hasan al-Bashry (kelompok Mu'tazilah). Keempat kitab ini membahas dengan lengkap ilmu ushul Fiqh dan dijadikan sebagai kitab induk yang melabirkan kaidah-kaidah ushul."

Al-Ghazali menyatakan dalam al-Mankbûl bahwa Ushul Fiqih dibangun berdasarkan tiga landasan, yaitu: Kalam, Bahasa (lughah), Fiqih. Ilmu kalam dijadikan sebagai pijakan dasar Ushul Fiqih, karena daya jangkaunya bersifat umum yang menjadi pijakan atas keyakinan seorang ahli ushul dalam menerima hukum-hukum syara' yang bersumber dari keyakinan terhadap keberadaan rasul sebagai pembawa risalah. ${ }^{5}$

Bahasa sebagai pijakan keduaUshul Fiqih setelah Kalam. Al-Ghazali menganggap demikian karena seorang ahli ushul bertugas sebagai pendorong ilmu kalam dalam memahami makna khithab (hukum), ta'wil berita dari rasul dan nash (teks) al-Qur'an. Sedangkan pijakan yang ketiga adalah fiqih dipandang oleh al-Ghazali sebagai objek dalil yang akan melahirkan hukum melalui upaya maksimal para mujtahid. ${ }^{6}$

al-Ghazali dalam al-Mustashfa mengatakan bahwa Ushul Fiqih adalah ilmu yang sangat mulia keberadaannya, karena ilmu ini adalah perpaduan antar 'aqli dan naqli. Melalui ilmu Ushul Fiqih inilah dimensi ketuhanan dan kemanusiaan bergabung menjadi satu dan melahirkan hukum-hukum yang bersifat praktis. Atas perpaduan itulah maka 'aqli dan naqli

$$
\begin{aligned}
& \text { تم إنى ابتدأت بعلم الكلام فصلته وعقلنه وطلعت كنب المحقين منهم وصنفت فيه ما أردت أن أصنف فصادفته علما وافيا }
\end{aligned}
$$

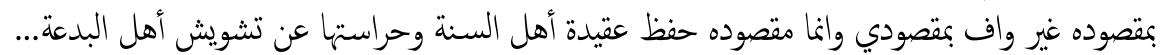

${ }^{5}$ Abu Hamid al-Ghazali, al-Mankhûl Min Ta'lîât al-Ushûl (Damaskus: Dar el-Fikr, 1980) Muhaqqiq: Muhammad Hasan Haytu. Halaman. 4. Lihat juga dalam Abd al-Wahhab Ibrahim Abu Sulayman, alFikr al-Ushûly: Dirâsah Tahlîliyyah Naqdiyyah (Jeddah: Dar el-Syuruq, 1983). Cet. I, halaman. 22-23. Pendapat di atas juga disepakati oleh murid al-Ghazali yaitu al-Amidi. Lihat Aly Ibn Muhammad alÂmidi, al-I hkâm Fî Ushûl al-A hkầm (Riyadh: Dar al-Shumay'iyy, 2003), cet. I, halaman. 21-22.

${ }^{6}$ Al-Ghazali.,al-Mankhûl Min Ta'lî́ât al-Ushûl, halaman. 22 
dalam ilmu ushul fiqih menjadi dua sisi mata uang yang tidak dapat dipisahkan. ${ }^{7}$ Al-Ghazali mengungkapkan:

$$
\begin{aligned}
& \text { وأشرف العلوم ما ازدوج فيه العقل والسمع واصطحب فيه الرأي والشرع وعلم الفقه وأصوله من هذا القبيل فإنه }
\end{aligned}
$$

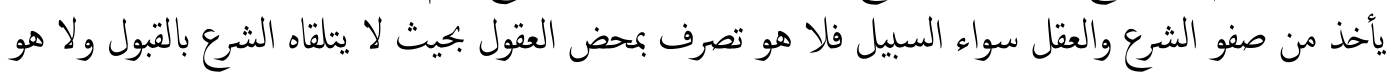

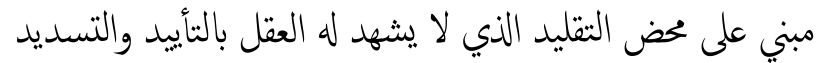

"Ilmu yang paling utama ialah ilmu yang memadukan antara aqli dan naqli secara seimbang. Keutamaan ini terdapat dalam ilmu fiqih dan ushul fiqih, sebab pada kedua ilmu tersebut terdapat keserasian secara seimbang antara peran akal dan wabyu; tidak, terlalu memibak pada teks syara', juga tidak terlalu bebas mengikuti akal."

\section{B. Teori / Konsep}

\section{Teori al-Tashwîb Fî al-Ijtihâd}

Teori al-Mushawnibât Fî al-Ijtihâd adalah teori yang menyatakan bahwa setiap hasil ijtihad itu (pasti) benar (Kullu Mujtahid[in] Mushîb[un] Fi Ijtibadihi). Teori ini dinyatakan oleh Pengikut Madzhab Asy'ari (Asy'ariyyah), Mu'tazilah, al-Ghazali dan alBaqillani. ${ }^{8}$ Teori ini dikenal dengan istilah al-Mushawwibah, sedangkan teori sebaliknya dikenal dengan teori al-Mukaththi ab yang diusung oleh jumhur ulama dan Iman alSyafi'i, mereka mengatakan bahwa kebenaran produk hukum ijtihad itu hanya satu (alMushîbu Wâhid[un]). Kedua teori ini lahir karena perbedaan sudut pandang ke dua madzhab ushul dalam penetapan hukum-hukum syara' terhadap masalah fiqih yang bersifat ijtihadiyah. Madzhab pertama meyakini bahwa hukum ijtihadiyah tidak ditetapkan secara pasti oleh Allah swt. tetapi hukum itu ditetapkan atas dugaan kuat mujtahid (Ghalabah al-Mujtahid) ketika ia berijtihad, maka produk hukum hasil ijtihad pasti benar (Shawâb) dan akan melahirkan ragam kebenaran yang pasti benar. Sedangkan madzhab kedua berpendapat bahwa Allah swt. telah menetapkan hukum terhadap masalah-masalah fiqih. Oleh karena itu, madzhab ini berpendapat bahwa

\footnotetext{
${ }^{7} \mathrm{Al}-\mathrm{Ghaza} l i$, al-Mustashfâ Min 'ilm al-Ushûl (Libanon: Dar al-Kutub al-'ilmiyyah, 2000). Halaman. 3.

${ }^{8}$ Pergulatan pemikiran kalam Asy'ari dan Mu'tazilah sepintas dapat 'didamaikan' dengan konsep ini. Padahal dibalik persamaan itu, tetap saja menyimpan perbedaan yang tajam antara Asy'ari dengan Mu'tazilah seperti halnya perbedaan mereka dalam tema-tema hukum yang lain. Kelahiran Asy'ari merupakan anti tesa terhadap pemikiran Mu'tazilah yang dibawa sejak lahir. Karena secara historis, kelahiran Madzhab As'ary merupakan reaksi keras Abu Hasan al-Asy'ari terhadap pemikiran kalam Washil bin Atha sebagai tokoh Mu'tazilah. Titik perbedaan Konsep Mushawwibah Asy'ariyyah dengan Mu'tazilah terletak pada proses dan hasil. Mu'tazilah berpendapat bahwa Allah swt. menetapkan hukum terhadap kasus ijtihadiyyah, namun ketepan hukum itu harus diupayakan oleh seorang mujtahid dengan cara ijtihad, oleh karena itu yang menjadi persoalan tidak terletak pada tuntutan produk ijtihadnya, namun kebenaran itu terletak pada aspek prosesnya. Hal ini berbeda dengan Asy'ari yang menyatakan bahwa Allah swt. tidak menetapkan hukum dengan pasti terhadap kasus ijtihadiya, namun hukum itu ditentukan berdasarkan dugaan kuat seorang mujtahid dalam berijtihad. Jika mau jujur, sesungguhnya esensi konsep al-Mushawwibah kedua madzhab kalam di atas sama yaitu kebenaran aspek ijtihad dinilai berdasarkan usaha seorang mujtahid, namun karena mereka sudah 'terlanjur' tesa-antitesa, maka tetap saja persamaan itu harus terlihat berbeda walau dari sisi penggunaan bahasa.
} 
kebenaran itu mutlak milik Allah swt, sedangkan produk hukum hasil ijtihad ada dua kemungkinan yaitu; mungkin benar dan mungkin salah (Khatha). ${ }^{9}$

Bagi kelompok al-Mushawnibah, kata "khatha" (salah) hanya digunakan dalam wilayah-wilayah dalil yang bersifat Qath'i saja. Sebab kesalahan dalam wilayah Qath'i, mengakibatkan dosa (itsm) yang berimplikasi pada predikat kafir bagi orang yang berbeda pendapat dalam wilayah-wilayah Qath'i. oleh karena itu, terminologi Khatha' (salah) hanya digunakan dalam wilayah-wilayah Qath'i saja, sebab perbedaan pendapat dalam wilayah ini berdosa dan pelakunya berstatus kafir. Sedangkan terminologi Shawab (benar) hanya berlaku pada wilayah-wilayah zhanny yang akan melahirkan pahala (tsawab) . Menurut al-Ghazali dalam wilayah zhanni ini tidak mengenal istilah dosa (lâ Itsma Fî al-Zhanniyyât). Jadi perbedaan pendapat diantara dua aliran ushul di atas, pada prinsipnya hanya terjadi pada penggunaan istlah Khatha'- Shawâb, Khatha' hanya digunakan pada wilayah Qath'iyyat yang melahirkan dosa dan predikat kafir bagi pelakunya jika berbeda. Sedangkan Shawâb (benar) digunakan pada wilayah Zhanniyyat yang akan melahirkan pahala bagi pelakunya. Oleh karena itu, pada prinsipnya bahwa produk hukum hasil ijtihad bernilai pahala (tsawâb) bagi seorang mujtahid. ${ }^{10}$

Menurut al-Ghazali, wilayah-wilayah pemikiran yang bersifat Qath'i (alNaşhariyyat al-Qath'iyyat) ada empat macam, yaitu: (1) Kalâm. Tema pembahasan yang termasuk dalam objek ini adalah keberadaan alam adalah baru (buduts), sifat-sifat bagi Allah, Bi'tsah al-Rasûl (pengutusan rasul), Ru'yatullah (melihat Allah). Semua objek pembahasan wilayah kalam di atas, ditetapkan berdasarkan wahyu dan bersifat Qath'i, maka berbeda pendapat dalam wilayah ini berdosa hukumnya dan pelakunya menyandang status kâfir. (2) Ushûl Fiqh. Wilayah ushul fiqih meliputi Ijmâ', Qiyâs dan Hadits Ahâd keberadaannya sebagai hujjah yang harus disepakati. Berbeda pendapat dalam wilayah ini berdosa dan pelakunya kâfir. (3) Fiqib Qath'i. Setiap pengetahuan agama yang sudah disepakati secara pasti, dan tidak ada khilaf di dalamnya (Mâ 'ulima

${ }^{9}$ Zuhayli, Ushul Fiqh al-Islamy, Juz. 2, halaman. 1124-1125.

${ }^{10}$ Kritik tajam Wahbah al-Zuhayli terhadap kubu Madzhab al-Mushawwibah terletak pada ragam kebenaran produk hukum hasil ijtihad. Menurut Zuhayli, implikasi paradigma hukum ini akan melahirkan dua benturan hukum yang saling kontradiktif satu sama lain dalam satu kasus hukum. Selain itu juga, kritik lainnya adalah kemungkinan terjadinya perbedaan hukum hasil ijtihad disebabkan syaratsyarat tekhnis seorang mujtahid ketika berijtihad. Bagi al-Zuhayli sebagai pengikut kelompok alMukhthi'ah, kemungkinan-kemungkinan implikasi paradigma hukum di atas sangat rentan terjadi dalam melahirkan konflik klaim kebenaran dalam hukum fiqih yang dilahirkan oleh dugaan seorang mujtahid satu dengan mujatahid lainnya dalam hukum yang sama. Sebab bagi al-Zuhayli, perbedaan hukum tidak dikhawatirkan jika terjadi dalam hukum yang sama tapi dalam kasus yang berbeda seperti, halal makan daging bagi jika dalam kondisi dharurat (mengancam keselamatan jiwa), namun haram jika sebaliknya. Bagi penulis kritik di atas tidak selayaknya ditujukan pada al-Ghazali dan madzhabnya, jika al-Zuhayli memahami dengan baik penggunaan istilah Khata'-shawab dan Qath 'i-Zhanny yang digunakan oleh alGhazali. Sebab pada prinsinya kosep al-Mushawwibah al-Ghazali dan kawan-kawan tidak seburuk apa yang dimaksud al-Zuhayli. Jika menelaah perbedaan sudut pandang kedua kubu di atas dari prespektif hadits riwayat Amru Bin al-Ash yang riwayat bil maknanya menyatakan bahwa apabila seorang hakim berijtihad lalu benar ijtihadnya, maka ia mendapat dua pahala, namun jika salah, maka ia mendapat satu pahala. Pada kesimpulannya hadits itu menyatakan bahwa ijtihad itu semuanya benar yang membedakan adalah pahala di sisi Allah swt. jadi menyerang pemikiran madzhab al-Mushawwibah dengan sudut pandang al-Zuhaili dan Al-Syaukani adalah keliru. Kritik ini dapat di lihat dalam Wahbah al-Zuhayli, Ushul Fiqh al-Islamy, halaman. 1130 dan 1133. 
min al-Dîn bi al-Dharûrah). Contoh wilayah ini yaitu, kewajiban shalat, kewajiban zakat, kewajiban puasa ramadhan, bilangan rakaat dalam shalat. Berbeda pendapat dalam wilayah ini berdosa dan pelakunya dinyatakan kâfir. (4) Hukum Fiqih berdasarkan Ijma'. Wilayah ini meliputi hukum bagia seperenam bagi kakek dalam waris, pengangkatan para Khalifah setelah Rasulullah saw. Berbeda pendapat pada wilayah ini berdosa dan pelakunya dinyatakan bersalah (mukhthi)

Berikut ini kutipan pendapat al-Ghazali tentang konsep Qath'i dan Zhanni dalam al-Mustashfâ Min 'ilm al-Ushûl:

$$
\begin{aligned}
& \text { النظريات تنقسم الى ظنية وقطعية فلا اثم فى الظنيات اذ لا خطأ فيها والمخطع في القطعيات } \\
& \text { آتم والقطعيات ثلاية أقسام كلامية وأصولية وفقهية اما الكلامية فنعنى بها العقليات المحض فئين }
\end{aligned}
$$

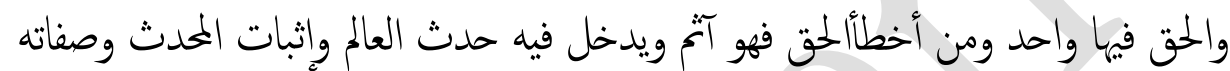

"Konsep-konesp ilmu dalam Islam terbagi dua, yaitu: Zhanny (dugaan) dan Qath'i (keyakinan). Dalam wilayah ilmu yang bersifat zhanny, tidak mengakibatkan dosa karena tidak ada kesalahan dalam wilayah itu. Berbeda dengan wilayah ilmu yang bersifat Qath'i yang berakibat dosa jika terjadi kesalahan. Wilayah ilmu yang bersifat Qath'i, ada tiga macam; ilmu kalam, ushul fiqih dan fiqib. Yang dimaksud dengan wilayah qath'i yaitu ilmu yang bersifat rasional murni yang hanya memiliki satu kebenaran. Oleh karenanya, kesalahan dalam wilayah ini mengakibatkan dosa. Masalah-masalah kalam yang termasuk ke dalam wilayah qath'i yaitu sifat baru bagi alam, penetapan makbluk dan sifatmya..."

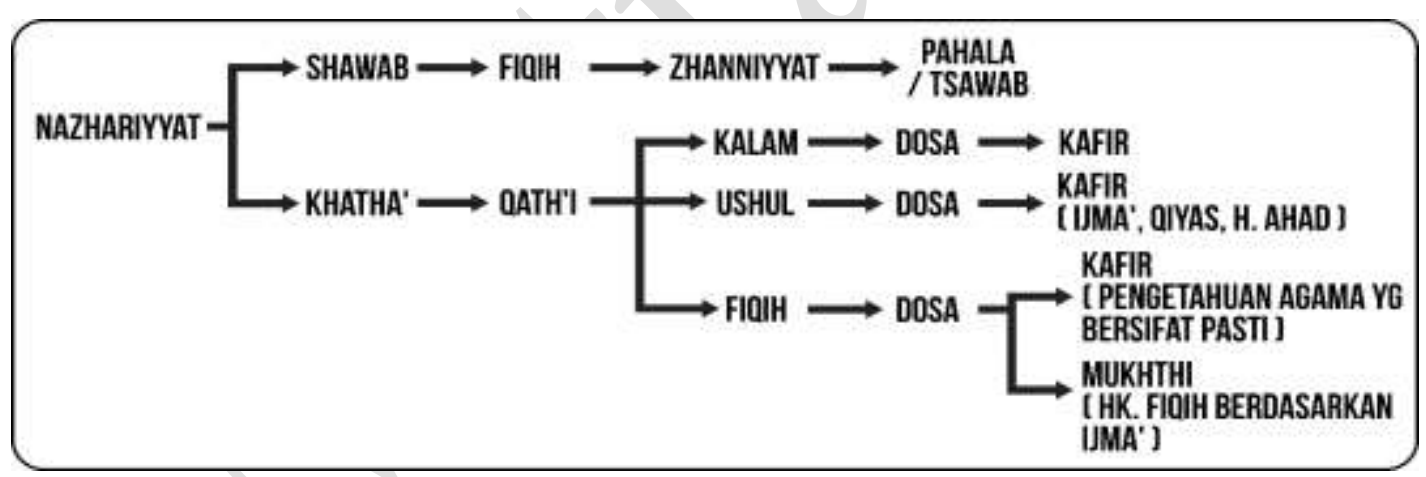

\section{Epistemologi Hukum Menurut Al-Ghazali \\ Menurut al-Ghazali hukum adalah ${ }^{11}$ :}

\footnotetext{
${ }^{11} \mathrm{Abu}$ Hâmid Muhammad Ibn Muhammad al-Ghazâli, al-Mustashfâ Min ilm al-Ushûl (Beitu: Dar elFikr, t.th). Juz. I, halaman. 55. Dalam mendefinisikan hakikat hukum, al-Ghazali dalam al-Mustashfa
} 


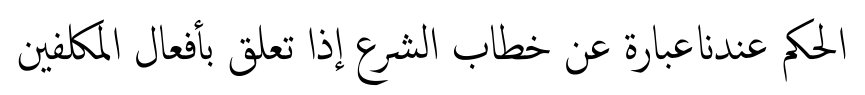

"Hukum menurut kami adalahseruan syara' yang berkaitan dengan perbuatan mukallaf."

Selanjutnya, al-Ghazali membagiseruan hukum menjadi tiga bentuk, yaitu ${ }^{12}$ :

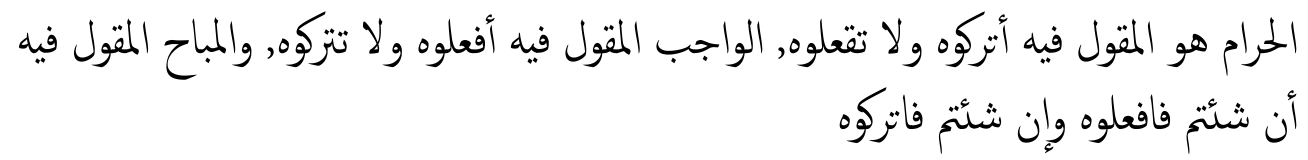

"Haram adalah pernyataan dengan kalimat 'tinggalkanlah oleh kalian' dan 'jangan kalian kerjakan', wajib adalah pernyataan dengan kalimat, 'kerjakanlah oleb kalian' dan 'janganlah kalian tinggalkan', dan mubah adalah pernyataan dengan kalimat,'jika kalian berkenan, maka kerjakanlah, dan jika kalian tidak berkenan, maka tinggalkanlah'.

Berdasarkan penjelasan di atas, al-Ghazali dengan tegas mendefinisikan hukum secara istilah dengan dua kata kunci yaitu khithâb al-Syar'i (seruan syara') dan af'âl almukallafin (perbuatan mukallaf). ${ }^{13}$ Dengan kedua rumus tersebut, al-Ghazali membagi seruan syara' yang terkait dengan perbuatan mukallaf menjadi tiga bagian; (1) haram, (2) wajib, (3) mubah. Sebagai penegas, al-Ghazali menyatakan bahwa jika tidak ditemukan seruan dalam bentuk khitâb (amar dan nahi) di atas dari al-Syâri' (Allah swt), maka tidak ada hukum bagi seorang mukallaf. ${ }^{14}$ Hal ini secara tegas ia laporkan dalam alMustashfaa sebagai berikut;

$$
\text { فإن لم يوجد هذا الخطاب من الثارع فلا حكم }
$$

"jika tidak ditemukan seruan bukum dari al-Syari" (Allah swt), maka tidak ada bukum."

Pernyataan al-Ghazali di atas menegaskan bahwa hakikat hukum berasal dari alSyâri' (sebagai subjek) yang berbentuk seruan (khithâb) untuk perbuatan mukallaf (sebagai objek). Dalam pernyataan sederhana ini sesungguhnya al-Ghazali memiliki konsep penalaran hukum bahwa seruan (khithâb) al-Syar'i yang berkaitan dengan perbuatan mukallaf hanya bersumber dari Allah swt. pernyataan itu bermakna bahwa selain al-Syâri' tidak memiliki otoritas untuk menentukan hukum. Korelasi makna hakikat hukum di atas terlihat dalam ragam bentuk khitab yang melahirkan tiga ragam hukum yang lahir dari seruan al-Syâri' yaitu; haram, wajib dan mubah. ${ }^{15}$

menggunakan frase “'indanâ” (menurut pendapat kami) hal ini menunjukkan bahwa defini hukum yang ia sampaikan adalah definisi yang telah disepakati oleh para ushûly golongan Asy'ary, hal ini jika ditelusuri ternyata pendapat yang sama juga dikutip oleh al-Razi dalam kitab al-Mahshûl fi ilm alUshûl, al-Amidi, al-Ihkâm Fî Ushûl al-Ahkhâm, Al-Asnawi, Nihâyah al-Saul dalam kitab al-Ibhâj Syarh al-Minhâj.

${ }^{12}$ ibid.,

${ }^{14}$ ibid.,

15 ibid., 
Penalaran hukum pertama ini menegaskan bahwa hukum Islam lahir dari seruan Allah swt. dalam bentuk perintah (amar), larangan (nahi) dan kebolehan (mubab). Khithâb al-Syâri' menolak terhadap otoritas perbuatan mukallaf menetapkan hukum dengan sendirinya. Definisi al-Ghazali menegaskan tentang teori kedaulatan hukum sepenuhnya berada pada Tuhan. Dengan demikian, al-Ghazali menegaskan bahwa sumber kebenaran berpangkal pada wahyu sebagai otoritas mutlak dalam menetukan hukum. ${ }^{16}$

Pembahasan hakikat hukum menurut pandangan al-Ghazali merupakan persoalan yang paling penting dalam kajian ushul fiqih. Hal ini ia dahulukan sebelum membahas beberapa tema lainnya, karena pemahaman hakikat hukum akan berpengaruh terhadap tema-tema pembahasan Ushul Fiqih yang lainnya. Kesalahan dalam memahami hakikat hukum, akan melahirkan kesalahan cara pandang ketika menghukumi sifat suatu benda ataupun perbuatan mukallaf. Melalaui pembahasan hakikat hukum ini, sesungguhnya al-Ghazali hendak meluruskan kesalahan cara pandang pemikiran kaum Mu'tazilah yang saat itu sedang merebak di tengah-tengah masyarakat. Selain itu al-Ghazali juga ingin menegaskan keyakinannya bahwa tidak ada ruang selain al-syâri' untuk menentukan hukum terhadap perbuatan mukallaf dan sifat suatu benda. ${ }^{17}$

\section{Metode Penelitian}

Untuk memberikan analisisnya, penelitian ini menggunakan metode kualitatif dengan pendekatan studi kepustakaan. Adapun sumber dalam penelitian ini adalah kitab alMustashfâ Min 'Ilm al-Ushûl karya Imam al-Ghazali dengan analisis teori al-Tashwîb Fî al-Ijtihâd.

\section{Analisis Corak Pemikiran Hukum Teologi Asy'ariyyah}

Penggunaan kata indanâ dalam mendefinisikan hakikat hukum mencerminkan bahwa Al-Ghazali adalah Asy'ariyyah (pengikut madzhab hukum Abu Hasan al-Asy'ari). Hal ini dapat dibuktikan melalu pendekatan motode triangulasi data beberapa kitab yang memiliki sanad dengan Madzhab Asy'ari, yaitu Abu Hasan al-Asyari dalam kitab al-Ibânah, Abu Bakar ibn Thayyib al-Bâqillâni dalam kitab Taqrîb al-Ushûl dan Abû Ma'âly al-Juwainy kitab al-Burbân dan al-Syâmil. Konsep hukum yang difahami oleh al-Ghazali dalam alMustashfa secara mutawâtir diriwayatkan dari gurunya yang bermadzhab Asy'ari. Konsep hukum yang diyakini al-Ghazali didapatkan dari gurunya yaitu al-Juwaini secara langsung juga secara tidak langsung dari al-Baqillani dan Abu Hasan al-Asy'ari melalui pendekatan alIqna (metode kebenaran yang diyakini tanpa mengalami langsung hanya menerima sepihak saja). ${ }^{18}$

Hakikat hukum menurut al-Ghazali bersifat top dow, artinya hukum bersumber dari al-Syâri' bukan dari akal yang menerima pancaran dari benda atau perubuatan yang memiliki

\footnotetext{
${ }^{16}$ ibid.,

${ }^{17}$ ibid.,

${ }^{18}$ Analisis Tafsir data
} 
hukum dengan sendirinya. ${ }^{19}$ Jika otoritas hukum hanya bersumber dari al-Syâri', maka hukum yang lahir dari perbuatan manusia, sifat benda, dan akal semuanya tertolak, sebab ketiga aspek tersebut berpotensi melahirkan hukum yang semuanya bermuara pada akal manusia semata. ${ }^{20}$

Ada perbedaan sudut pandang antara kelompok Asy'ariyyah dengan Mu'tazilah ketika memahami hakikat hukum yang dikaitkan denga perbuatan manusia dan benda. Menurut Mu'tazilah bahwapahala dan dosa pada setiap perbuatan manusia, pada hakikatnya menjadi hak prerogatif mutlak Allah swt. sehingga setiap perbuatan mukallaf, tidak harus bergantung pada seruan Tuhan. Artinya ada atau tidak ada seruan Tuhan, perbuatan itu sudah memiliki hukum dengan sendirinya. Tugas manusia dengan akal yang Allah berikan adalah tinggal memilih antara perbuatan baik dan buruk menurut akal. Dalam persoalan ini bagi kaum mu'tazilah akal dijadikan sebagai al-Hâkim yang dapat menentukan perbuatan baik dan buruk manusia. Dengan pemahaman lain, konsep ini mengisyaratkan bahwa setiap perbuatan dan sifat benda, memancarkan hukum dengan sendirinya, sehingga keberadaan hukum itu menjadi pembeda antara yang satu dengan yang lainnya. kemudian dari pancaran dari hukum setiap benda itu direspon oleh akal, dan pada akhirnya akal lah yang akan menyimpulkan hukum yang melekat pada benda dan perbuatan itu berdasarkan sudut pandang akal yang diterima dari pancaran sifat benda dan perbuatan tersebut. Maka lahirlah hukum baik-buruk pada benda dan perbuatan berdasarkan sifat dan perbuatan masingmasing. ${ }^{21}$

Al-Ghazali secara cemerlang menempatkan fungsi akal secara proporsional. Akal sebagai anugrah Tuhan bagi manusia memiliki potensi untuk memahami sumber hukum dari al-Syâri. Namun dibalik kelebihannya itu, akal tetap tidak diberikan kewenangan untuk menentukan hukum. Oleh karena itu, bagi al-Ghazali posisi akal ketika dihadapkan pada sumber hukum dan objek hukum hanya bersifat mediator saja. Akal berposisi sebagai objek dan wahyu difungsikan sebagai sumber hukum yang akan difahami oleh akal dalam menghukumi objek perbuatan mukallaf. Intinya akal tidak dapat mengetahui hukum secara mandiri tanpa bimbingan wahyu.

Namun harus diakui bahwa polemik antara al-Ghazali dengan Mu'tazilah tentang posisi akal dalam mengetahui hukum, terletak pada kesalahan fahaman diagnosa al-Ghazali terhadap konsep hukum yang difahami mu'tazilah. Titik perbedaan sudut pandang itu terletak pada apakah akal dapat mengetahui hukum secara mandiri atau tidak.

Al-Ghazali menempatkan sebagai anti tesa secara berlawanan dengan Mu'tazilah. Sebagai pengikut Madzhab Asy'ari, al-Ghazali pada hakikatnya hendak meneguhkan konsep kalam Ahl al-Sunnah wa al-Jama'ah sebagai kelompok kalam yang berbeda secara diametral dengan Mu'tazilah yang dimasukkan ke dalam pembahasan Ushul Fiqih. Hal ini terlihat sejak awal bahwa al-Ghazali menegaskan bahwa kalam termasuk ilmu yang bersifat Kully dan Ushul Fiqih merupakan ilmu yang bersifat Juг'i. Berdasarkan paradigma inilah, alGhazali mendudukkan Ushul fiqih sebagai sub ordinat dari Ilmu Kalam. Ilmu Kalam yang

\footnotetext{
${ }^{19}$ Analaisis Tafsir data

${ }^{20}$ Analaisis Tafsir data

${ }^{21}$ Refleksi Tafsir (RT)
} 
diyakini oleh al-Ghazali yaitu kalam yang di transmisi dari gurunya yaitu Abu Ma'ali alHaramain al-Juwaini al-Asy'ari. Pegaruh sanad dan intelektualitas keilmuan inilah yang membentuk pemahaman kalam al-Ghazali hingga menjadi seorang mujtahid pengikut madzhab Asy'ari yang militan.

Metode dalam memahami sumber ilmu pengetahuan yang diyakini al-Ghazali banyak dilakukan melalu pendekatan al-Iqna'. Keyakinan kepada ucapan seorang guru tanpa mem-verifikasi lebih lanjut menjadi tradisi kuat proses peneriamaan kalangan Madzhab Asy'ari. Tradisi inilah sebagai identitas yang mudah untuk diketahui bahwa al-Ghazali adalah pengikut madzhab al-Asy'ari. Selain itu, kelahiran Madzhab Mu'tazilah yang mengusung ide kalam berbasis aliran filsafat ini, menajadi cikal bakal lahirnya teologi Asy'ariyyah sebagai upaya untuk menyerang dan mematahkan kesalahan teologi Mu'tazilah yang sudah dianggap sesat sejak awal kelahiran Madzhab Asy'ari. Latar belakang inilah yang melahirkan tulisan-tulisan al-Ghazali dalam bidang filsafat yang banyak meyerang para filosof seperti Ibnu Rusyd. Gaya dan style cara al-Ghazali dalam menulis kitab filsafat yang sarat dengan bantahan dan kritik ide kesesatan filosof dan Mu'tazilah ini, mempengaruhi gaya penulisan dan cara pandang al-Ghazali dalam menulis Kitab al-Mustashfa Min ílm alUshul. Style itu terlihat dalam pernyataan al-Ghazali ketika menyerang ide Mu'tazilah dengan ungkapan fâsid, bâthil, yang menghiasi sepanjang penulisan kitab al-Mustashfâ. Selain itu, banyaknya pendapat Mu'tazilah yang di kutip, mencerminkan bahwa hakikatnya alGhazali hendak menyerang dan menunjukkan kesalahan ide Mu'tazilah dalam wilayah hukum sebagai dampak dari kesesatan cara pandang mereka dalam masalah Kalam yang dipengaruhi oleh ide filsafat.

Berdasarkan cara pandang itulah, al-Ghazali selalu berbeda dan berusaha tampil beda dengan Mu'tazilah. Kalaupun ada titik persinggungan dengan Mu'tazilah, al-Ghazali tetap tidak mengakui persamaan itu. Seperti penggunaan akal dalam berijtihad, menempatkan akal sebagai media untuk mengenal Allah swt, menggunakan Qiyas sebagai dalil aqli dan kesamaan konsep lainnya. Intinya al-Ghazali dalam al-Mustashfa hendak membuat garis pembeda secara tegas antara Asy'ari dengan Mu'tazilah dari akar hinnga ke daun, dan perbedaan itu menegaskan seperti air dengan minyak yang tidak akan pernah menyatu selamanya. Padahal bila diperhatikan dengan teliti, sesungguhnya Asy'ari merupakan refleksi dari Mu'tazilah dalam hal membantah argumentasi akal dengan akal. Sekalipun al-Ghazali mengklaim berbeda dalam menempatkan akal dalam berijtihad, namun dalam tataran aplikasi di lapangan, al-Ghazali pun menyerang argumentasi Mu'tazilah dengan akal secara seimbang. Hal ini terlihat dari logika-logika mantik yang sering dijadikan argumen oleh al-Ghazali dalam membantah pendapat Mu'tazilah. Pendekatan inilah yang terlihat kental dalam setiap masalah yang dibahas dalam setiap tema pembahasan ushul figh dalam kitab al-Mustashfa Min ilm al-Ushul.

\section{E. Simpulan}

Pemikiran ushul fiqih al-Ghazali sangat dipengaruhi oleh madzhab kalam dan kondisi sosial politik yang berkembang pada saat al-Ghazali menulis kitab al-Mustashfa Min ilm al-Ushul. Pengaruh kalam dalam al-Mustashfa Min 'ilm al-Ushul sangat signifikan. Hal ini 
terlihat ketika al-Ghazali memposisikan ilmu ushlul dan fiqih sebagai wilayah qath'i yang sederajat dengan ilmu kalam, sehingga paradigma al-Ghazali ini terlihat tegas dalam menyikapi perbedaan pendapat dalam masalah hukum, hingga nampak dengan jelas bahwa al-Mustashfa min ilm al-Ushul adalah kitab perpaduan antara Ushul al-din dan Ushul fiqih sebagai pijakan yang akan melahirkan hukum (fiqih) melalui ijtihad yang digali dari sumbersumber hukum Islam.

Al-Ghazali pada hakikatnya tidak berbeda dengan Mu'tazilah, karena ia menyerang argumen Mu'tazilah dan kelompok lain secara subjektif hingga fanatisme terhadap madzhab Asy'ari menyeretnya pada perangkap subjektifitas akal yang ia cela. Al-Ghazali selaku pengikut madzhab Asy'ari tidak berbeda dengan Mu'tazilah dalam memfungsikan akal sebagai media untuk melahirkan hukum. fungsi akal diperankan oleh al-Ghazali dalam metode Ta $\underline{h} q \hat{q} q$ al-Manâth, sedangkan Mu'tazilah memerankan akal dalam menggali hukum dengan istilah bi Imsâk al-Syarîah.

Metode Iqna' yang digunakan al-Ghazali dalam menerima informasi dari al-Juwaini dan al-Baqillani dijadikan sebagai kebenaran yang diyakini tanpa pembuktian dan verifikasi, hingga pengetahuan itu dijadikan argumen al-Ghazali untuk meluruskan kesalahan Mu'tazilah, akibatnya al-Ghazali melanjutkan tradisi kesalahan yang di transmisi secara mutawatir dari gurunya.

Paradigma hukum Madzhab al-Mushawwibah menutup ruang ragam kebenaran dalam wilayah kalam dan Wilayath Qathiyyat baik dalam Ushul fiqih maupun bidang fikih. Konsep Nazhariyyat Qath'iyyat yang dikemukakan al-Ghazali merupakan upaya proteksi pemikiran Kalam madzhabAsy'ari dari pengaruh pengaruh pemikiran kalam Mu'tazilah, yang berimbas pada masalah fiqib dan bahasa.*

\section{DAFTAR PUSTAKA}

A. Sirri, Mun'im. Sejarah Fikih Islam Sebuah Pengantar, Surabaya: Risalah Gusti, 1995.

Abdul Qadir, Muhammad al-`Arusy. al-Masâ`il al-Musytarakah Bayna Ushûl Fiqh wa Ushûl al-Dîn, t.tp:tp.

Abdurrahman, Hafidz. Pengaruh Filsafat dan Ilmu Kalam Terhadap Kemunduran Dunia Islam, Bogor: Al-Azhar Freshzone, 2016.

Abu Rusytah, Atha. Taysîr al-Wushûl ilâ al-Ushûl Dirâsât fì Ushûl Fiqh, Beirut: alUmmah, 2000.

Abu Sulayman, Abd al-Wahhab Ibrahim. al-Fikr al-Ushûly: Dirâsah Tahlîliyyah Naqdiyyah, Cetakan I, Jeddah: Dar el-Syuruq, 1983.

Abu Zahrah, Muhammad. Târîkh al-Madzâhib al-Islâmiyyah : Fi al-Siyâsah wa al'Aqâid Wa Târîkh al-Mâdzahib al-Fiqhiyyah, Kairo: Dar el-Fikr al-'Araby, t.th. Ushûl Fiqh, Kairo: Dâr el-Fikr al-Araby, t.th.

Adlan, Athiyyah. al-Nazhariyyah al-Âmah Li Nizhâm al-Hukm Fî al-Islâm, Cetakan I, Kairo: Dar el-Kutub al-Mishriyyah, 2011. 
al-'Uwaid, Abd al-Aziz Ibn Muhammad Ibn Ibrahim. Ma'alim Fi al-Manhaj, Kuwait: Wizarah Awqaf, 2011.

al-Âmidi, Aly Ibn Muhammad. al-Ihkâm fî Ushûl al-Ahkâm, cetakan I, Riyadh: Dar alShumay'iyy, 2003.

al-Ashfahâny, 'Allâmah al-Râghib. Mufradât al-Fâzh al-Qur'ân, Beirut: Dar elSyamiyyah, cet ke-2, 1997.

al-Ba'mary, Muhammad bin Farhun. Tabshirah al-Hukkam Fi Ushul al-Aqdhiyyah wa Manahij al-Ahkam, Riyadh: Dar Alim al-Kutub, t.th.

al-Badawy, Abd Al-Rahman. Ibn al-Rusd Talkhish "al-Qiyas" Li Aristhu, t.tp: t.p, 1988.

al-Bâqillâny, al-Qâdhi Aby Bakar Muhammad Bin al-Thayyib. al-Taqrîb wa al-Irsyâd fî Ushûl Fiqh, cetakan I, Beirut: Dâr el-Kutub al-'Ilmiyyah, 2012.

al-Baydhawi, Nashir al-Din Umar. Mishbah al-Arwah Fi Ushul al-Din, t.tp: Dar elRazi, 2008.

,al-Minhâj Ma'a Syahay al-Isnawy wa al-Badkhasy, Juz III,

al-Ghazali, Abu Hamid. al-Munqidz Min al-Dhalâl, Lubnan: Dar el-Fikr, 1993.

al-Mankhûl Min Ta'lîqât al-Ushûl, Muhaqqiq: Muhammad Hasan Haytu,

Damaskus: Dar el-Fikr, 1980..

, Mahakk al-Nazhar, www.al-mostafa.com.

, al-Mustashfâ Min 'ilm al-Ushûl, Libanon: Dar al-Kutub al-'ilmiyyah, 2000.

..........., Asas al-Qiyas, Riyadh: Maktabah al-'Ibikan, 1993.

, Tahafut al-Falasifah, Muhaqqiq: Sulaiman Dunya, Mesir: Dar el-Ma'arif, t.th.

al-Hafif, 'Aly. Asbab Ikhtilaf al-Fuqaha, Kairo: Dar el-Fikr al-Araby, t.th.

al-Hanafi, Abu Yusuf dan al-Syafi'i. Sejarah Fikih Islam Sebuah Pengantar, Surabaya : Risalah Gusti, 1995.

al-Hasanât, Ahmad Ibrâhim Hasan. Tathawwur al-Ushûliy 'inda al-Mutakallimîn, cetakan I, Yordan: Dar an-Nur, 2015.

al-Husain, Abd al-Qadir Muhammad. Imam ahl al-Haqq Abu Husayn al-Asy'ari, Damaskus: al-Masyriq li al-Kitab, 2010.

al-Husny, Umar Sa'ady 'Abbas. Mafhûm al-Qiyâs 'inda al-Ghazâli: Dirâsah Tahliliyyah Muqâranah, t.tp: tp, t.th.

al-Ihsan, Muhammad 'Amim. al-Ta'rifat al-Fiqhiyyah, Beirut: Dar el-Kutub al'Ilmiyyah, 2003.

al-Jabbâr, Qâdhi abd. Syarah al-Ushûl al-Khamsah, Muhaqqiq. Abd Karim Utsman, t.tp: Maktabah Wahbah, t.th.

al-Jauziyyah, Ibnu Qayyim. Jâmi’ al-Fiqh, Juz VII, t.tp: Dar el-Wafa, 2000.

al-Jawziyyah, Syams al-Dîn Abû Bakar Bin Qayyim. I'lâm al-Muwaqqi'în 'an Rabb al'Alamîn, Juz I, Kairo: Maktaba Ibnu Taymiyyah, t.th.

al-Jayzany, Muhammad Husain. Manhajiyyat Ushuliyyah, Riyadh: Maktabah al-Rusd, 2013. 
al-Jazairy, Abu Bakar Jabir. Hâdzâ al-habîb Muhammad Shalla al-Allahu 'alyhi wa sallam, Cetakan 4, Dar al-Salam, Mesir:2004.

al-Jurjawi, Ali Ahmad, Hikmah al-Tasyr` wa falsafatuhu, juz-1, Beirut : Dar al-Fikr. 1994.

al-Juwaini, Haramayn. Hawamis 'ala al-'Aqidah al-Nizhamiyyah, Kairo: Dar elThiba'ah, 1984.

al-Irsyad 'Ila Qawath'I al-Adillah Fi Ushul al-I'tiqad, Mesir: Maktaba alHanji, 1950.

al-Khudhary, Muhammad. Ushûl al-Fiqh, Kairo: Dar el-Hadits, 2003.

al-Maraghi, Ahmad Mustafa. Tafsir Al-Maraghi, Beirut: Dar el-Fikr, t.th.

al-Maturidy, Abi Mu'in Maymun al-Nasafi. Tabshirah al-Adillah Fi Ushul al-Din, Mesir: Maktabah al-Azhar, 2011.

al-Mutazily, Abû al-Husain Muhammad bin al-Thayyib al-Bashry. al-Mu'tamad fî Ushûl al-Fiqh, Juz II, Damaskus: Institut Francis De Damas, 1965.

al-Nabhani, Taqiyuddin. al-Tafkîr, penerjemah: Taqiyuddin al-Siba'i, t.tp: Hizb alTahrîr, 1973.

Nizham al-Islam, Cetakan VI, t.tp: Hizb al-tahrir. 2001.

............,al-Syakhshiyyah al-Islâmiyyah, Cetakan III, t.tp: Hizb al-Tahrîr: 2005.

al-Nadwi, Ali Ahmad. al-Qalwaid al-Fiqhiyyah: Mafhumuha, Nasy'atuha, Tathawwuruha, Dirasah Mu'allafatiha, Adillatiha, Muhimmatiha, Tathbiqatiha, Damaskus: Dar el-Qalam: 2005.

al-Nadwi, AbuHasan. Rijal al-Fikr wa ad-Da'wah fi al-Islam, Beirut: Dar Ibnu Katsir, 2007.

al-Namlah, Abdul Karim Aly Bin Muhammad. al-Muhadzdzab Fi 'ilm Ushûl al-Fiqh al-Muqârin: Tahrîr Li Masâilihi Wa Dirâsatuhâ Dirasah Nazhariyyah Wa Tathbîqiyyah, Cetakan I, Riyadh: Maktabah al-Rusyd, 1999.

al-Nasysyâr, Âly Sâmi'. Manâhij al-Bahts 'inda Mufakkiry al-Islâmi: Waktisyâfi alManhaj al-Ilmy Fi al-'Âlam al-Islâmy, Beirut: Dar el-Nahdhah al-'Arabiyyah, 1984.

al-Nu'mah, Ibrahim. Ushul al-Tasyri' al-Dustury Fi al-Islam, Baghdad: Diwan alWaqf, 2009.

al-Qarâfy, Syihab al-Dîn Abû al-‘Abbâs Ahmad Ibn Idrîs. Syarah Tanqîh al-Fushûl Fî Ikhtshâr al-Mahshûl fî al-Ushûl, Beirut: Dar el-Fikr, 2004.

al-Qaththân, Manna' Khalîl. Târikh Tasyrî̀ al-Islâmy: al-Tasyrî̀ wa al-Fiqh, Cetakan II, Riyadh: Maktabah Ma’arif, 1997.

al-Qayyim, Ibn. I'lam al-Muwaqqi'in 'an Rabb al-'Alamin, Riyadh: Dar Ibn elJawziyyah, 1424.

al-Qurâfy.SyarahTanqîh al-Fushûl fi Ikhtishar al-Mahshul fi al-Ushul, Beirut: Dar elFikr, 2004.

al-Razzâq, Mustafa ‘Abd. Tamhîd li Târîkh al-Falsafah al-Islâmiyyah, Kairo: t.p, 1949. 
al-Sa'dîy, 'Abd al-Hakîm 'Abd al-Rahmân As'ad. Mabâhits al-'Illah Fî al-Qiyâs 'inda al-Ushûliyyîn. Cetakan ke. 2. Libanon, 2000.

al-Sanûsy, Abd al-Rahmân Ibn Mu'ammar. al-Ijtihâd Bi al-Ra'yi Fî̀ Ashr al-Khilâfah al-Rasyîdah: Dirâsah Tahlîyyah Fî Ushûl Siyâsah al-Tasyri' wa Maqâshidihi wa Târikhihi, Kuwait: Wizârah Awqâf Wa Sy’ûn al-Islâamiyyah, 2011.

al-Shabuni, Muhammad Ali. Rawâ'i al-Bayân Fî Tafsîr Ayât al-Ahkam Min al-Qur'an, Jakarta: Dar al-Kutub al-Islamiyyah, 2001.

al-Shallaby, 'Aly Muhammad. Dawlah al-Salâjiqah wa Burûz al-Masyrû' Islâmy Li Muqâwamah al-Taghalghul al-Bhâthiny wa al-Ghazw al-Shalîby , Cetakan I, Kairo: Mu'assasah Iqra', 2006.

al-Iman Ghazali wa Juhuduhu fi al-Islah wa al-Tajdid al-'Alimul Kabir wa Murabbi asy-Syahir Syaikh Abdul Qodir al-Jailani (Terjemah), Cetakan II, Jakarta: Beirut Publishing, 2017.

al-Suyûthy, Jalâluddîn Aby 'abd al-Rahmân. Lubâb al-Nuqûl fì Asbâb al-Nuzûl, Mesir: Dar Ibn al-Jawzy, 2013.

al-Syafi'i, Aby Muzhaffar Ibn Muhammad Ibn Abd al-Jabbar al-Sam'âny. Qawâthi' alAdillah Fi Ushul al-Fiqh, Cetakan I. Juz I, Riyadh: Maktabah al-Tawbah, 1999.

al-Syâfi'i, Muhammad Bin Idrîs. al-Risâlah, Muhaqqiq: Ahmad Syâkir, Kairo: Dâr elAtsâr, 2008.

al-Syahrâny, Aydh Ibn 'Abdullah Ibn 'Abd al-'Azîz. al-Tahsîn wa al-Taqbîh al'Aqliyyâny: Wa Atsarahumâ Fî Masâil Ushûl Fiqh Ma'a Munâqasyat[in] 'Ilmiyyat[in] Li Ushûl al-Madrasah al-'Aqliyyah al-Hadîtsah, Juz I, Kunûz Isybiliya: t.p, t.th.

al-Syâtiby, Abû Ishâq. al-Muwâfaqât Fî Ushûl al-Syarî'ah, Cetakan I, Libanon: Dar elKutub al-'Ilmiyyah, 2004.

al-Syaukâny, Muhammad Bin 'Aly. Irsyâd al-Fuhûl Tahqîq al-Haq Min 'ilm al- 'Ushûl, Riyadh: Dar el-Fadhilah, 2000.

al-Syuwaikh, Âdil. Ta'lîl al-Ahkâm fî al-Syarî'âh al-Islâmiyyah, Thantha: Dar al-Basyir li al-Tsaqâfah wa al-Ulûm, 2000.

al-Zarkasyi. al-Bahr al-Muhîth fî Ushûl al-Fiqh, Juz I, Kuwait: Wizarah al-Awqaf wa al-Syu un al-Islamiyyah bi al-Kuwait, 1992.

al-Zarqa, Musthafa Ahmad. al-Madkhal Ila Nazhariyyah al-Iltizam al-Ammah, Damaskus: Dar el-Qalam, 1999.

al-Zuhayli, Wahbah. Ushul Fiqh, Juz II, Beirut: Dar el-Fikr, 2001.

Anwar, Saeful. Filsafat Ilmu al-Ghazali Dimensi Ontologi dan Aksiologi, Bandung: Pustaka Setia, 2007.

Anwar, Syaiful. Epistemologi Hukum Islam dalam al-Mustashfa min al-'Ilm al-Ushul Karya al-Ghazali (450-505 H/ 1058-1111 M). PPS IAIN Sunan Kalijaga, Yogyakarta, 2000.

Arifin, Bustanul. Pelembagaan Hukum Islam di Indonesia: Akar Sejarah, Hambatan dan Prospeknya, Cetakan I, Jakarta: Gema Insani Press, 1996. 
Badawi, Abd al-Rahman. Mu'allafat al-Ghazali, Kuwait: Wakalah al-Mathbu'at, 1977.

Baltaji, Muhammad. Manahij al-Tasyri' al-Islami fi al-Qurni ats-Tsani al-Hijri: Dirasah Ushuliyah Muqaranah li Mushadir al-Ahkam Inda al-A'imah, Kairo: Dar el-Salam, 2004.

Batsa, Ahmad Tamyur. Nazhrah Tarikhiyyah Fi Huduts al-Madzahib al-Fiqhiyyah alArba'ah: al-Hanafy, al-Maliky, al-Syafi'I, al-Hanbaly wa Intisyariha 'inda Jumhur al-Muslimin, Beirut: Dar el-Qadiri, 1990.

Beyk, Khudlory. Târikh Tasyri' al-Islâmy, Cetakan VII, Indonesia : Dar al-Ihya alKutub al-Arabiyyah, 1981.

......,Muhadharat Tarikh al-Umam al-Islamiyyah al-Dawlah al-'Abbasiyyah, Beirut: Dar al-Qalam, 1986.

Bin Zabair, Fakhruddin. Adillah al-Qawa'id al-Ushuliyyah Min al-Sunnah alNabawiyyah, Oman: Dar el-Atsariyyah, 2010.

Dahlan, Abdul Azis, et. al. Ensiklopedi Hukum Islam, Jakarta : PT Ichtiar Baru Van Hoeve, 2003.

Fakhry, Muhammad Riyadh. Tathawwur al-'alâqah bayn 'Ilm Ushûl al-Fiqh Wa Ushûl al-Dîn Wa Atsaruhu Fi al-Masâil al-Ushûliyyah, Iraq: Jami’ah Baghdad, t.th.

al-Anshary, Muhammad Ibnu Nizhamuddin.Fawâtih al-Rahamût, Juz 2, Beirut: Dar elFikr, t.th.

Fawzi Ramdan. Epistemologi Hukum Islam: Pemikiran Syekh Fakhruddin al-Razy (L. 554 H/W.606 H) Tentang Sumber dan Illat Hukum. PPS UIN Bandung, 2013.

Fudah, Sa'id. Ta'ammulat Fi al-Fikr al-Falsasy 'Inda al-Imam al-Asy'ary, Mesir: t.p, 2010.

Hasan, Khalid Ramadhan. Mu'jam Ushul al-Fiqh, t.tp: al-Rawdhah, t.th.

Huda, Nurul. Teori Tashwib Abu Hamid al-Ghazali (450 H/505 H) dalam al-Mustashfa min 'Ilm al-Ushul dan Relevansinya dengan Pengembangan Metodologi Hukum Islam di Indonesia, PPS UIN Sunan Gunung Djati, Bandung, 2017.

Ibn Amîr. al-Kâmil Fî Ushûl al-Dîn: Fi Iktishâr al-Syâmil Fî Ushûl al-Dîn li Imâm alHaramayn, Muhaqqiq: Jamâl 'Abd al-Nâshir al-Mun'im, Juz. II, Kairo: Dâr alSalâm, 2010.

Ibn Katsir, 'Imad al-Din Ismail Ibn Umar. Thabaqat al-Syafi'iyyah, Libanon: Dar elKutub al-Wathaniyyah, 2004.

Ibn Khaldun. Muqaddimah, Beirut: Dar al-Ijil, t.th.

Ibn Rusd. al-Dharury Fi Ushul al-Fiqh, Beirut: Dar el-Gharab al-Islamy, 1994.

Ismatullah, Deddy. Sejarah Sosial Hukum Islam, Bandung: Tsabita, 2008.

Kansil. Pengantar Ilmu Hukum dan Tata Hukum di Indonesia, Jakarta: Balai Pustaka, 2002.

Khallâf, 'Abd al-Wahhâb. Mashâdir al-Tasyrî' al-Islâmy Fîmâ Lâ Nashsha Fîhi, Cetakan II, Kuwait: Dar el-Qalam, 1972.

, Khulâshah Târîkh al-Tasyri' al-Islâmy, cetakan 9, t.tp: t.p, 1971. 
Lisan, Hamdan dan Fawzi al-Anjary. Ahl al-Sunnah al-Asya'irah: Syahadah Ulama alUmmah wa Adillatuhum, t.tp: Dar el-Dhiya, t.th.

Lutfi, Khairur Rizal. "Teori Hukum Alam dan Kepatuhan Negara Terhadap Hukum Internasional.” Jurnal Yuridis, No. 1, Vol.1 (Juni 2014): 96

Madkur, Muhammad Salam. Manâhij al-Ijtihâd fî al-Islâm, Kuwait: al-Ashriyyah Kuwait, 1974.

Mahmud, Abd al-Majid. al-Ittijahat al-Fiqhiyyah 'inda Ashhab al-Hadits Fi al-Qarn alTsalits al-Hijri, t.tp: tp, 1979.

Mubarak, Jaih. Sejarah dan Perkembangan Hukum Islam, Cetakan III, Bandung : Rosdakarya, 2003.

Nasution. Metode Penelitian Naturalistik Kualitatif, Bandung: Tarsito, 1996.

Nawawi, Hadari dan Martini Hadari. Instrumen Penelitian Bidang Sosial, Yogyakarta: UGM Press, 1995.

Praja, Juhaya S. Filsafat Hukum Islam, Tasikmalaya: Latifah Press, 2009.

....., Filsafat Hukum Islam, Bandung: LPPM Unisba, 1995.

....., Filsafat Ilmu; Menelusuri Struktur Filsafat Ilmu dan Ilmu-ilmu Islam, Bandung: Program Pascasarjana, 2009.

....., Teori Hukum dan Aplikasinya, Bandung: Pustaka Setia, 2011.

Qal'ah Jiy, Muhammad Ruwwâs. al-Mawsû'ah al-Fiqhiyyah al-Muyassarah, Juz I, Beirut: Dar el-Nafâis, 2010.

Salamah, Aby Islam Mustafa Bin Muhammad. al-Ta'sîs Fî̀ Ushûl al-Fiqh 'Alâ Dhaw' al-Kitâb wa al-Sunnah, t.tp: Maktabah al-Haramain, t.th.

Suratmaputra, Ahmad Munif. Filsafat Hukum Islam al-Ghazali: Mashalah Mursalah dan Relevansinya dalam Pembaharuan Hukum Islam, Jakarta: Pustaka Firdaus, 2013.

Syuwaikit, Adil. Ta'lil al-Ahkam, t.tp: t.p, t.th.

Thawîlah, Abd al-Wahhâb 'abd al-Salâm. Atsar al-Lughah fî Ikhtilâf al-Mujtahidîn, Kairo: Dar el-Salam, t.th.

Tsa'laby, Ahmad. Târîkh al-Tasyrî' al-Islâmy wa Târîkh al-Nuzhum al-Qadhâ'iyyah fî al-Islâm Ma'a Buhûts Idhâfiyyah 'an al-Qur'ân al-Karîm, Kairo: Maktabah alNahdhah al-Mashriyyah, t.th.

Utsman, Mahmud Hamid. al-Qâmûs al-Mubîn: Isthilâhât al-Ushuliyyîn, Riyadh: Dar el-Zahr, 2002.

Zallûm, Abdul Qadîm. Nizham al-Hukm Fî al-Islâm, t.tp: Hizb al-Tahrîr, 2002.

Zumar, Muhammad. "Hukum Alam: Perkembangan, Sumbangan dan Prospeknya", Makalah (IAIN Surakarta), t.d. 